\title{
Determining the Level of Health Awareness among Hospitality Students: A Case Study of the Faculty of Tourism and Hotels at Minia University in Egypt \\ Mohamed T. A. Abdelmawgoud \\ Faculty of Tourism and Hotels- Minia University
}

\begin{abstract}
This research aims to determine the level of health awareness and the level of health locus of control among hospitality students. The simple random sample of the study consisted of 95 firststage students of the hotel management department at the faculty of tourism and hotels in Minia university during the first semester of the academic year 2019/2020. The study results revealed that the degree of the health awareness level and the health locus of control level are high. In addition, they are significant differed according to the gender in favor of males. Moreover, there is a direct correlation between the level of health awareness and the level of health locus of control $(r=0.444, \mathrm{Sig}=000)$. Finally, the regression model of the level of health awareness $(\mathrm{Y})$ with the level of health locus of control $(\mathrm{X})$ is $\mathrm{Y}=1.955+0.513 \mathrm{X}$.
\end{abstract}

Keywords: Health Awareness, Health Locus of Control, Hospitality Students.

\section{Introduction:}

In general, health refers to the absence of disease, physical, mental, and social well-being (ICPD, 1994). It is a basic human need for the successful functioning of individuals and societies (Wittayapun et al., 2010). Thus, health means freedom of any kind of diseases and the harmony between all organs and parts of the body (Researchomatic, 2012). The health literacy strategy is useful in reducing disparities in health related to education. Thus, health literacy has an essential effect on the relationship between low educational level and poor health (Heide et al., 2013). Consequently, health hazardous behaviors contribute very clearly to the destruction of the human health (Refaat, 2014). Accordingly, attention must be paid to the level of health awareness. In this context, health awareness refers to the ability of the individual himself, his family and his community to access, understand and benefit from information in ways that promote and maintain good health, and therefore it is considered an essential factor in ensuring good health outcomes (WHO, 2016). The level of health control refers to individual beliefs based on experiences in health issues and external or internal control, can affect health and plays an important role in health behaviors (Pourhoseinzadeh et al., 2017). The results of the researches that measured the level of health awareness have varied, it is a high level (Alonazi et al., 2016), a medium level (Abdalhaqq et al., 2012; Al-Sharaa, 2019), or a low level (Al-Ali, 2001; Gelany \& Moussa, 2012; Ashraah et al., 2013; Maaki, 2017; Iqbal et al., 2020) among students.

Education is a fundamental social determinant of health, which it is an upstream cause of health (Truman \& Hahn, 2015). Consequently, poor health, not only results from lower educational attainment, it can also cause educational setbacks and interfere with schooling (VCU, 2015). The recent decades have witnessed a radical change in the diseases' types and their outbreak in the community, from infecting diseases to chronic ones, particularly the diseases which are called the living style illnesses such as heart diseases, blood pressure diseases, and diabetes besides (Senthilkumar \& Ulaganathan, 2017). Today, human beings are provided with lots of facilities, but they have also suffered with severe health issues. Therefore, the health awareness may save humans from different health problems at earliest as it reaches to severity (Iqbal et al., 2020). Globally, there has been increasing concern about university students reporting mental health conditions, yet their mental health needs remain mostly unaddressed (Bardi, 2020). Thus, mental health awareness is an important issue for all educators. Consequently, they realize that there is a great deal that can be done to help students with mental health issues (Barile, 2020). A good 
quality education is the foundation of health and well-being, as people to lead healthy and productive lives, they need knowledge to prevent sickness and disease (UNESCO, 2020). Consequently, the problem of this study measures the level of health awareness and the level of health locus of control among students of the hotel management department at the faculty of tourism and hotels at Minia university.

\section{Literature Review}

There were many concepts that dealt with the health awareness, as it was defined as the translation of health knowledge and experiences into behavioral patterns among individuals (O'liewa, 1999). In addition, it is the introduction of facts, data, and health information related to health and disease to the members of society in an attempt to arrive at the situation when everyone is ready to respond to health instructions and guidelines (Mursi, 2005). Moreover, a health-conscious person is the ideal individual who enjoys high standards of health, social, mental, and physical integration (Ahmad, 2012). Finally, health awareness is a comprehensive understanding of health, and it is the basic concept of living a healthy life that makes sure that you do not get sick and are able to live an optimal lifestyle (Senthilkumar \& Ulaganathan, 2017). Several studies have dealt with measuring the level of health awareness among students in different educational stages. The level of health awareness was low among primary school students in government schools in Palestine (Al-Ali, 2001), Egyptian university students (Gelany \& Moussa, 2012), and students of the Hashemite University in Jordan (Ashraah et al., 2013), and secondary school students (Iqbal et al., 2020). There is also a decrease in the level of health awareness among the rural population in Egypt (Maaki, 2017). On the other hand, the level of health awareness was a high level among students at the colleges of applied medical sciences in the kingdom of Saudi Arabia (Alonazi et al., 2016). Finally, the level of health awareness was an average level among students of An-Najah national universities and Jerusalem in Palestine (Abdalhaqq et al., 2012), and Ajloun college students at the Balqa applied university (Al-Sharaa, 2019).

Factors that significantly affect the level of health awareness have varied, they include gender, place of living, mother academic level, father academic level, and the students' achievement in science among primary school students in government schools in Palestine (Al-Ali, 2001). Besides, the level of health awareness differed according to the place of living, where urban girls have better knowledge of health awareness compared to rural girls in India (Mahajan \& Sharma, 2005). In addition, this level differed according to the type of university, the type of faculty, and the total of the grades (Abdalhaqq et al., 2012). In particular, the level of reproductive health awareness among female students in Egyptian universities has decreased, which is attributed to age, social and cultural factors such as the level of education (Gelany \& Moussa, 2012). Moreover, the level of health awareness differed according to age, gender in favor of females and the educational level in favor of fourth year students (Al-Arjan et al., 2013). There are significant differences in the level of health awareness among students at the Hashemite University in Jordan, according to the factors of gender, specialization, academic level, and GPA (Ashraah et al., 2013). Regarding the level of health locus of control, it differs according to the factors of scientific specialization and marital status. Besides, there is a correlation between the level of health awareness and the level of health locus of control (Khalafy, 2013). Moreover, the level of health control does not differ between males and females (Azzouz \& Jabali, 2014).

Regarding the Egyptian rural population, the level of health awareness varied according to the factors of gender, age, educational, economic, and social levels (Maaki, 2017). There was no statistically significant difference between males and females in performing, the majority of roles related to implementing health education activities in their schools (Almohaithef \& Elsayed, 
2019). There are statistically significant differences in health behavior levels among Ajloun college students at the Balqa Applied University according to gender in favor of females. In addition, there is a positive correlation between healthy behavior and fitness level (Al-Sharaa, 2019). There is a significant difference of health awareness between public and private institutes in favor of the private school students. Moreover, it is recommended that there may be inclusion of knowledge about health awareness in the syllabus (Iqbal et al., 2020). Finally, lifestyle behaviors differ among high school students in urban and semi-urban areas. Consequently, health education targeted at secondary schools must be improved to improve the students' lifestyle behaviors (Cai et al., 2020).

The behavior of tobacco, alcohol, drug, and risky sexual behavior correlated positively with the level of risky health behavior in Egypt. Moreover, the main determinants of risky behavior included male students, elderly students, students with high financial allowances, and the lack of concern for risk (Refaat, 2014). College students are at high risk of developing smoking habits as they are exposed to a greater availability of cigarettes and close connections with their smokers' peers. The prevalence of smoking among students at Kafr El-Sheikh University in Egypt was 11\% (Amin et al., 2016). Moreover, there was a positive correlation between the health-related performance and the nutritional literacy $(r=0.32)$ (El-Wakeel \& El-Ahmady, 2017). Moreover, training improves the safety competencies of hospitality students, which it is crucial to include safety competencies in the curriculum to increase students' safety awareness (Bossema, 2017). Finally, the level of work motivation accounts for about $34-50 \%$ of mental health problems among employees (Kotera et al., 2018).

Adolescent food choices do not conform to dietary guidelines (Story et al., 2002). Besides, food safety perceptions influence adolescents' food choices. Therefore, it needs to examine the behavioral and environmental factors that influence healthy eating behavior (Verstraeten et al., 2014). In particular, teens face high nutritional risks, overweight, obesity and anemia during their growth period (Banna et al., 2016). As a result, 12 and 19 years of age are obese and more than a third of them are overweight (Azar et al., 2020). Finally, a study of Pinto et al., (2020) recommended that legislation restricting food and drink advertising should be in place to protect young people from unhealthy food advertisements in Canada.

\section{Methodology}

This research aims to determine the level of health awareness and the level of health locus of control among hospitality students. Therefore, the method depends on the quantitative approach. The study population consisted of 290 first-stage students. Consequently, the simple random sample of the study consisted of $165(32.8 \%)$ first-stage students of the hotel management department at the faculty of tourism and hotels in Minia university during the first semester of the academic year 2019/2020 (Surveysystem, 2020). In addition, this study used the scale of health awareness that is designed by Abdelhaq et al., (2012), to measure the level of health awareness, and the scale of the health locus of control, which is designed by Wallston et al., (1978) to assess a person's beliefs regarding whether his health description is determined by the actions of individuals, unlike chance. Consequently, the data collection tool is a questionnaire for hospitality students. The results of scales are interpreted according to the following percentages; $80 \%$ and above is a very high level of health awareness, 70-79.9\% a high level, 60-69.9\% an average level, 50-59.9\% a lower level, and less than $50 \%$ a deficient level. This research tests the following hypotheses:

1. There is a significant difference among students in the level of health awareness according to the gender. 
2. There is a significant difference among students in the level of health awareness, according to the economic level.

3. There is a significant difference among students in the level of health awareness, according to the place of living.

4. There is a significant difference among students in the health locus of control level according to gender.

5. There is no significant difference among students in the health locus of control level according to the economic level.

6. There is a significant difference among students in the health locus of control level according to the place of living.

7. There is a significant correlation between the level of health awareness and the health locus of control level.

\section{Data Analysis and Results Discussion}

About 165 questionnaires were distributed to the first-stage students, 100 of them returned, and 95 questionnaires are valid for the statistical analysis. By analyzing the study data, the results of the study came as the following:

Table 1: The Demographic Data of Respondents

\begin{tabular}{|c|l|l|c|c|}
\hline $\mathbf{N}$. & \multicolumn{1}{|c|}{ Factors } & \multicolumn{1}{|c|}{ Items } & Frequency & Percent \\
\hline 1 & \multirow{2}{*}{ Gender } & Male & 48 & 50.5 \\
\cline { 3 - 5 } & & Female & 47 & 49.5 \\
\hline 2 & \multirow{2}{*}{ Place of Living } & City & 50 & 52.6 \\
\cline { 3 - 5 } & & Village & 45 & 47.4 \\
\hline \multirow{2}{*}{3} & \multirow{2}{*}{ Economic Level } & Poor & 14 & 14.7 \\
\cline { 3 - 5 } & & Average & 67 & 70.5 \\
\cline { 3 - 5 } & & High & 14 & 14.7 \\
\hline
\end{tabular}

Table (1) reflects that the numbers of males and females are almost equal. 52,6\% are coming from a city. Concerning the economic level, about $70.5 \%$ of students have an average economic level, $14.7 \%$ a high level and $14.7 \%$ a low economic level.

Table 2: The Level of Health Awareness between Hospitality Students

\begin{tabular}{|c|l|c|c|c|c|}
\hline No & \multicolumn{1}{|c|}{ Items } & Mean & Std. & $\mathbf{\%}$ & Level \\
\hline 1 & I care that the daily food is integrated and comprehensive. & 4.26 & 0.948 & 85.2 & $\begin{array}{c}\text { Very } \\
\text { high }\end{array}$ \\
\hline 2 & I cannot eat breakfast due to the limited time. & 3.69 & 1.082 & 73.8 & High \\
\hline 3 & Drink more cold or hot drinks between main meals. & 3.62 & 1.169 & 72.4 & High \\
\hline 4 & Drinking coffee and tea helps me focus. & 3.42 & 1.373 & 68.4 & Average \\
\hline 5 & $\begin{array}{l}\text { I am interested in knowing the nutrients that give me an } \\
\text { energy. }\end{array}$ & 3.83 & 1.252 & 76.6 & High \\
\hline 6 & I keep my weight properly. & 3.80 & 1.078 & 76 & High \\
\hline 7 & Eating more fresh vegetables and fruits. & 3.83 & 1.108 & 76.6 & High \\
\hline 8 & I try to stay away from fried foods and prefer cooked foods. & 3.44 & 1.191 & 68.8 & Average \\
\hline \multicolumn{1}{|c|}{ Nutrition Domain } & 3.74 & 1.15 & 74.7 & High \\
\hline 9 & I care about sleep and rest for enough hours. & 3.89 & 1.276 & 77.8 & High \\
\hline 10 & $\begin{array}{l}\text { I care about showering, especially after sports and exercise. } \\
\text { I1 }\end{array}$ & 4.19 & 1.014 & 83.8 & $\begin{array}{c}\text { Very } \\
\text { High }\end{array}$ \\
\hline 11 & $\begin{array}{l}\text { When choosing my clothes, take into account the appropriate } \\
\text { air temperature. }\end{array}$ & 3.83 & 1.078 & 76.6 & High \\
\hline 12 & $\begin{array}{l}\text { I am interested in housing in a clean and healthy house in } \\
\text { terms of ventilation and sun. }\end{array}$ & 4.07 & 1.034 & 81.4 & $\begin{array}{l}\text { Very } \\
\text { High }\end{array}$ \\
\hline
\end{tabular}


International Journal of Heritage, Tourism and Hospitality Vol. (14), No. (1), June, 2020

\begin{tabular}{|c|c|c|c|c|c|}
\hline No & Items & Mean & Std. & $\%$ & Level \\
\hline 13 & $\begin{array}{l}\text { I care about trimming my hands and the feet-nails whenever } \\
\text { needed. }\end{array}$ & 4.01 & 1.144 & 80.2 & $\begin{array}{l}\text { Very } \\
\text { High }\end{array}$ \\
\hline \multicolumn{2}{|r|}{ Personal Health Domain } & 4.00 & 1.1092 & 80 & $\begin{array}{l}\text { Very } \\
\text { High }\end{array}$ \\
\hline 14 & I walk long distances to stimulate blood circulation. & 4.03 & 1.153 & 80.6 & $\begin{array}{l}\text { Very } \\
\text { High }\end{array}$ \\
\hline 15 & I like to participate in sports and recreational activities. & 3.66 & 1.234 & 73.2 & High \\
\hline 16 & I am interested in making time for some exercise. & 3.53 & 1.219 & 70.6 & High \\
\hline 17 & I stop exercising that leads to my injury. & 3.65 & 1.099 & 73 & High \\
\hline 18 & Avoid exercises, if you feel tired. & 3.57 & 1.098 & 71.4 & High \\
\hline 19 & $\begin{array}{l}\text { Participate in sports activities with the goal of feeling happy } \\
\text { and satisfied. }\end{array}$ & 3.71 & 1.138 & 74.2 & High \\
\hline 20 & $\begin{array}{l}\text { I am interested in making a medical examination after } \\
\text { recovering from an injury. }\end{array}$ & 3.43 & 1.217 & 68.6 & Average \\
\hline 21 & $\begin{array}{l}\text { I am interested in making a medical examination before } \\
\text { joining the sports team. }\end{array}$ & 3.42 & 1.243 & 68.4 & Average \\
\hline 22 & $\begin{array}{l}\text { Health care must be present for every student whose health } \\
\text { condition is registered. }\end{array}$ & 3.76 & 1.108 & 75.2 & High \\
\hline \multicolumn{2}{|r|}{ Sporting Activities } & 3.64 & 1.168 & 72.8 & High \\
\hline 23 & $\begin{array}{l}\text { I am interested in knowing the health conditions for the } \\
\text { sitting position when studying. }\end{array}$ & 3.91 & 1.230 & 78.2 & High \\
\hline 24 & $\begin{array}{l}\text { I am interested in knowing the conditions for correct walking } \\
\text { in the street. }\end{array}$ & 3.87 & 1.113 & 77.4 & High \\
\hline 25 & I cannot overstate my ability to carry things. & 3.80 & 1.097 & 76 & High \\
\hline 26 & I am interested in knowing how to carry the correct books. & 3.67 & 1.086 & 73.4 & High \\
\hline TV & I know the effect of exercise on moderate strength. & 3.72 & 1.108 & 74.4 & High \\
\hline rᄉ & $\begin{array}{l}\text { I am interested in knowing how to pick things up and carry } \\
\text { them from the ground. }\end{array}$ & 3.79 & 1.081 & 75.8 & High \\
\hline rq & $\begin{array}{l}\text { I am interested in knowing how to protect and maintain the } \\
\text { body. }\end{array}$ & 3.98 & 1.031 & 79.6 & High \\
\hline 30 & $\begin{array}{l}\text { I am interested in knowing the functioning of the vital } \\
\text { systems in my body. }\end{array}$ & 3.80 & 1.068 & 76 & High \\
\hline 31 & I avoid physical fatigue and stress. & 3.67 & 1.198 & 73.4 & High \\
\hline 32 & Doing sports activities to help the body perform its functions. & 3.93 & 1.196 & 78.6 & High \\
\hline \multirow{2}{*}{\multicolumn{2}{|c|}{$\begin{array}{c}\text { Body Domain } \\
\text { Total }\end{array}$}} & 3.81 & 1.12 & 76.28 & High \\
\hline & & 3.8 & 0.71 & 75.96 & High \\
\hline
\end{tabular}

Acordimng to table (2), the average of nutrition domain equals 3.74 out of 5 (74.73\%), this indicates a high level. More in detail, hospitality students should reduce the drinking of coffee and tea, stays away from fried foods, and move towards fully cooked foods. The level of personal health is a very high level (4 out of 5) by $80 \%$. In addition, the domain of sporting activities is 3.64 out of $5(72.8 \%)$, which indicates a high level. Moreover, the level of body domain is 3.81 out of $5(76.31 \%)$, which it indicates that this level is high. Finally, hospitality students have a very high level of the personal health, and a high level of body, nutrition, and sportive activities, respectively. The level of health awareness equals 3.8 out of $5(76 \%)$, which is a high level.

Table 3: Descriptive Statistics of the Health Awareness Level.

\begin{tabular}{|l|l|l|l|}
\hline No & \multirow{2}{*}{ Tests } & Health Awareness Level \\
\cline { 4 - 4 } & \multicolumn{2}{|l|}{} & Value \\
\hline 1 & Mean & Statistic & 3.775 \\
\hline
\end{tabular}




\begin{tabular}{|l|l|l|l|}
\hline \multirow{2}{*}{ No } & Tests & Health Awareness Level \\
\cline { 3 - 4 } & \multicolumn{2}{|l|}{} & Value \\
\cline { 3 - 4 } & & $\begin{array}{l}\text { Std. } \\
\text { Error }\end{array}$ & 0.0577 \\
\hline 2 & $\begin{array}{l}95 \% \text { Confidence Interval for } \\
\text { Mean }\end{array}$ & $\begin{array}{l}\text { Lower } \\
\text { Bound }\end{array}$ & 3.66 \\
\cline { 3 - 4 } & & $\begin{array}{l}\text { Upper } \\
\text { Bound }\end{array}$ & 3.89 \\
\hline 3 & Median & 3.78 \\
\hline 4 & Maximum & 5 \\
\hline 5 & Minimum & 1.81 \\
\hline 6 & Variance & 0.316 \\
\hline 7 & Standard Deviation & 0.563 \\
\hline 8 & Normal Distribution & K-S & 0.745 \\
\cline { 3 - 4 } & & Sig & 0.635 \\
\hline
\end{tabular}

It is clear from the table (3) that the average of health awareness level among hospitality students is 3.8 out of 5 (76\%), which it indicates to a high level. In addition, the standard deviation is estimated at 0.56. This result is consistent with the study of Alonazi et al., (2016), while it differs with the studies of (Al-Ali, 2001; Gelany \& Moussa, 2012; Abdalhaqq et al., 2012; Ashraah et al., 2013; Alarjan et al., 2013; Maaki, 2017; Iqbal et al., 2020). Moreover, the distribution of the health awareness level follows the normal distribution. Therefore, parametric measures are used to calculate the differences between the study groups.

Table 4: The T-Test of the health awareness level according to the gender

\begin{tabular}{|l|c|c|c|c|c|c|}
\hline \multirow{2}{*}{ Domain } & \multicolumn{2}{|c|}{ Males } & \multicolumn{2}{c|}{ Females } & \multirow{2}{*}{ t-value } & \multirow{2}{*}{ Sig. } \\
\cline { 2 - 5 } & Mean & Std. & Mean & Std. & & \\
\hline Nutrition & 3.9505 & 0.65270 & 3.5213 & 0.63914 & 3.238 & 0.002 \\
\hline Personal Health & 4.0333 & 0.76779 & 3.9660 & 0.79599 & 0.420 & 0.676 \\
\hline Sporting Activities & 3.7708 & 0.70325 & 3.5059 & 0.61725 & 1.953 & 0.054 \\
\hline Body Awareness & 3.8917 & 0.67314 & 3.7340 & 0.73374 & 1.091 & 0.278 \\
\hline $\begin{array}{l}\text { Health } \\
\text { Level }\end{array}$ & 3.8945 & 0.55419 & 3.6529 & 0.55011 & 2.132 & 0.036 \\
\hline
\end{tabular}

It is evident from the table (4) that there are significant differences in the domain of nutrition according to gender in favor of males, while there are no differences in the domains of personal health, sporting activities and body. In addition, there is a significant difference in the level of health awareness between males and females in favor of males. This result agrees with the studies that have determined the existence of significant differences between males and females in the level of health awareness (Al-Arjan et al., 2013; Ashraah et al., 2013; Maaki, 2017). On the contrary, this result differed with the results of the study (Al-Arjan et al., 2013), which determined that the differences are in favor of females.

Table 5: T-Test of the Health Awareness Level according to the Place of Living.

\begin{tabular}{|l|c|c|c|c|l|l|}
\hline \multirow{2}{*}{ Domain } & \multicolumn{2}{|c|}{ City } & \multicolumn{2}{c|}{ Village } & \multirow{2}{*}{ t-value } & \multirow{2}{*}{ Sig. } \\
\cline { 2 - 6 } & \multicolumn{1}{|c|}{ Mean } & Std. & Mean & Std. & & \\
\hline Nutrition & 3.6575 & 0.72396 & 3.8278 & 0.61831 & $-1.226-$ & 0.223 \\
\hline Personal Health & 4.0520 & 0.75139 & 3.9422 & 0.81198 & 0.684 & 0.495 \\
\hline Sporting Activities & 3.7022 & 0.68730 & 3.5704 & 0.65503 & 0.955 & 0.342 \\
\hline Body & 3.7740 & 0.80883 & 3.8578 & 0.57267 & $-0.587-$ & 0.559 \\
\hline Health Awareness Level & 3.7681 & 0.62831 & 3.7826 & 0.48600 & -0.125 & 0.901 \\
\hline
\end{tabular}

It is evident from the table (5) that there is no difference according to the place of living, in the levels of health awareness, nutrition, personal health, sporting activities, and body. This result 
differs with the studies of Al-Ali (2001), and Mahajan \& Sharma (2005) which they recognized the existence of a significant difference between city and village residents in the level of health awareness. Moreover, the study of Mahajan \& Sharma (2005) stated that urban girls have a better knowledge of health awareness compared to rural girls.

Table (6): One-Way ANOVA of Health Awareness according to the Economic Level

\begin{tabular}{|c|c|c|c|c|c|c|}
\hline Domain & Source of Variance & $\begin{array}{c}\text { Sum of } \\
\text { Squares }\end{array}$ & $\begin{array}{c}\text { Degrees of } \\
\text { Freedom }\end{array}$ & $\begin{array}{l}\text { Mean of } \\
\text { Squares }\end{array}$ & $\begin{array}{c}\text { F- } \\
\text { Value }\end{array}$ & Sig. \\
\hline \multirow[t]{3}{*}{ Nutrition } & Between groups & 2.066 & 2 & 1.033 & \multirow[t]{3}{*}{2.311} & \multirow[t]{3}{*}{0.105} \\
\hline & Inside groups & 41.124 & 92 & \multirow[t]{2}{*}{0.447} & & \\
\hline & Total & 43.190 & 94 & & & \\
\hline \multirow{3}{*}{$\begin{array}{l}\text { Personal } \\
\text { Health }\end{array}$} & Between groups & 1.537 & 2 & 0.768 & \multirow[t]{3}{*}{1.276} & \multirow[t]{3}{*}{0.284} \\
\hline & Inside groups & 55.423 & 92 & 0.602 & & \\
\hline & Total & 56.960 & 94 & & & \\
\hline \multirow{3}{*}{$\begin{array}{l}\text { Sporting } \\
\text { Activities }\end{array}$} & Between groups & 0.285 & 2 & 0.142 & \multirow[t]{3}{*}{0.310} & \multirow[t]{3}{*}{0.734} \\
\hline & Inside groups & 42.153 & 92 & 0.458 & & \\
\hline & Total & 42.437 & 94 & & & \\
\hline \multirow[t]{3}{*}{ Body } & Between groups & 0.081 & 2 & 0.040 & \multirow[t]{3}{*}{0.080} & \multirow[t]{3}{*}{0.923} \\
\hline & Inside groups & 46.572 & 92 & .506 & & \\
\hline & Total & 46.652 & 94 & & & \\
\hline \multirow{3}{*}{$\begin{array}{l}\text { Health } \\
\text { Awareness } \\
\text { Level }\end{array}$} & Between groups & .451 & 2 & 0.226 & \multirow[t]{3}{*}{0.708} & \multirow[t]{3}{*}{0.495} \\
\hline & Inside groups & 29.290 & 92 & \multirow[t]{2}{*}{$.318^{\circ}$} & & \\
\hline & Total & 29.741 & 94 & & & \\
\hline
\end{tabular}

It is evident from the table (6) that there is no difference according to the economic level of hospitality students in the levels of health awareness, nutrition, personal health, sporting activities, and body. This result differs with the study of Maaki (2017).

Table (7): The Level of The Health Locus of Control.

\begin{tabular}{|c|c|c|c|c|c|}
\hline No & Items & Mean & Std. & $\%$ & Level \\
\hline 1 & $\begin{array}{l}\text { If I get sick, it is my own behavior, which determines } \\
\text { how soon I get well again. }\end{array}$ & 4.16 & 0.982 & 83.16 & Very High \\
\hline 2 & $\begin{array}{l}\text { No matter what I do, if I am going to get sick, I will get } \\
\text { sick. }\end{array}$ & 3.54 & 1.128 & 70.74 & High \\
\hline 3 & $\begin{array}{l}\text { Having regular contact with my physician is the best } \\
\text { way for me to avoid illness. }\end{array}$ & 3.59 & 1.125 & 71.79 & High \\
\hline 4 & $\begin{array}{l}\text { Most things that affect my health happen to me by } \\
\text { accident. }\end{array}$ & 3.34 & 1.217 & 66.74 & Average \\
\hline 5 & $\begin{array}{l}\text { Whenever I do not feel well, I should consult a } \\
\text { medically trained professional. }\end{array}$ & 3.63 & 1.167 & 72.63 & High \\
\hline 6 & I am in control of my health. & 3.47 & 1.228 & 69.47 & Average \\
\hline 7 & $\begin{array}{l}\text { My family has a lot to do with my becoming sick or } \\
\text { staying healthy. }\end{array}$ & 3.55 & 1.192 & 70.95 & High \\
\hline 8 & When I get sick, I am to blame. & 3.31 & 1.212 & 66.11 & Average \\
\hline 9 & $\begin{array}{l}\text { Luck plays a big part in determining how soon I will } \\
\text { recover from an illness. }\end{array}$ & 3.03 & 1.267 & 60.63 & Average \\
\hline 10 & Health professionals control my health. & 3.49 & 1.166 & 69.9 & Average \\
\hline 11 & My good health is largely a matter of good fortune. & 3.22 & 1.159 & 64.42 & Average \\
\hline 12 & $\begin{array}{l}\text { The main thing that affects my health is what I myself } \\
\text { do. }\end{array}$ & 3.54 & 1.040 & 70.74 & High \\
\hline 13 & If I take care of myself, I can avoid illness. & 3.63 & 1.305 & 72.63 & High \\
\hline 14 & $\begin{array}{l}\text { Whenever I recover from an illness, it is usually } \\
\text { because other people (for example, doctors, nurses, }\end{array}$ & 3.43 & 1.108 & 68.63 & Average \\
\hline
\end{tabular}


International Journal of Heritage, Tourism and Hospitality Vol. (14), No. (1), June, 2020

\begin{tabular}{|l|l|l|l|l|l|}
\hline No & \multicolumn{1}{|c|}{ Items } & \multicolumn{1}{|c|}{ Mean } & \multicolumn{1}{|c|}{ Std. } & \multicolumn{1}{c|}{ \%evel } & \multicolumn{1}{|c|}{} \\
\hline & family, and friends) have been taking good care of me. & & & & \\
\hline 15 & No matter what I do, I am likely to get sick. & 3.67 & 1.106 & 73.47 & High \\
\hline 16 & If it is meant to be, I will stay healthy. & 3.65 & 1.019 & 73.05 & High \\
\hline 17 & If I take the right actions, I can stay healthy. & 3.82 & 1.031 & 76.42 & High \\
\hline 18 & $\begin{array}{l}\text { Regarding my health, I can only do what my doctor } \\
\text { tells me to do. }\end{array}$ & 3.75 & 1.010 & 74.95 & High \\
\hline \multicolumn{2}{l}{ Mean } & 3.55 & 1.13 & 70.91 & High \\
\hline
\end{tabular}

Table (7) shows that the level of health locus of control equals 3.6 out of $5(70.91 \%)$, which is a high level. In addition, hospitality students have a very high level of awareness that their behavior determines the date of recovery upon exposure to disease. Students realize that most of the things that are on health happen by chance, and the ability to control health, Self-blame when exposed to illness. Luck plays a big role in determining the timing of recovery from illness, health professionals control health, good health is like great luck, and when recovering from illness, it is usually because other people (doctors, nurses, family, and friends) took good care of us.

Table 8: Descriptive Statistics of the Health Locus of Control Level

\begin{tabular}{|c|c|c|c|}
\hline \multirow[t]{2}{*}{ No } & \multirow{2}{*}{\multicolumn{2}{|c|}{ Tests }} & Health Locus of Control \\
\hline & & & Value \\
\hline \multirow[t]{2}{*}{1} & \multirow[t]{2}{*}{ Mean } & Statistic & 3.5456 \\
\hline & & Std. Error & 0.04995 \\
\hline \multirow[t]{2}{*}{2} & \multirow{2}{*}{$\begin{array}{l}95 \% \text { Confidence } \\
\text { Interval for Mean }\end{array}$} & Lower Bound & 3.4464 \\
\hline & & Upper Bound & 3.6448 \\
\hline 3 & \multicolumn{2}{|l|}{ Median } & 3.5000 \\
\hline 4 & \multicolumn{2}{|l|}{ Maximum } & 4.56 \\
\hline 5 & \multicolumn{2}{|l|}{ Minimum } & 2.61 \\
\hline 6 & \multicolumn{2}{|l|}{ Variance } & 0.237 \\
\hline 7 & \multicolumn{2}{|l|}{ Standard Deviation } & 0.48682 \\
\hline \multirow[t]{2}{*}{8} & \multirow[t]{2}{*}{ Normal Distribution } & $\mathrm{K}-\mathrm{S}$ & 0.0991 \\
\hline & & Sig & 0.280 \\
\hline
\end{tabular}

It is clear from the table (8) that the average of the health locus of control level is 3.6 out of 5 (72\%), which it refers to the high level. In addition, the standard deviation is 0.49. By comparison, there is a strong convergence between the level of health awareness and the level of health locus of control among hospitality students. Moreover, the distribution of the health locus of control level follows the normal distribution. Therefore, parametric measures are used to calculate the differences between the study groups.

Table 9: T-Test of The Health Locus of Control Level according to Gender and The Place of Living

\begin{tabular}{|c|c|c|c|c|}
\hline & \multicolumn{4}{|l|}{ Factors } \\
\hline & \multicolumn{2}{|c|}{ Gender } & \multicolumn{2}{|c|}{ The Place of Living } \\
\hline & Males & Females & City & Village \\
\hline Mean & 3.662 & 3.4267 & 3.6100 & 3.4741 \\
\hline Standard Deviation & 0.5033 & 0.4437 & 0.52435 & 0.4361 \\
\hline T-value & \multicolumn{2}{|l|}{2.415} & \multicolumn{2}{|l|}{0.365} \\
\hline Significance & 0.018 & & 0.176 & \\
\hline
\end{tabular}

According to table (9), there is a significant difference in the health locus of control level, according to the gender in favor of males. This result disagrees with the study of Azzouz \& 
Jabali (2014) which stated that the level of health locus of control does not differ between males and females.

Table 10: One-Way ANOVA of the Health Locus of Control Level, according to the Economic Level.

\begin{tabular}{|l|l|l|l|l|l|l|}
\hline Domain & Source of Variance & $\begin{array}{l}\text { Sum of } \\
\text { Squares }\end{array}$ & $\begin{array}{l}\text { Degrees of } \\
\text { Freedom }\end{array}$ & $\begin{array}{l}\text { Mean of } \\
\text { Squares }\end{array}$ & F-Value & Sig. \\
\hline \multirow{2}{*}{$\begin{array}{l}\text { The Health Locus } \\
\text { of Control }\end{array}$} & Between groups & 0.515 & 2 & 0.258 & 1.089 & 0.341 \\
\cline { 2 - 5 } & Inside groups & 21.762 & 92 & $.237 \cdot$ & & \\
\cline { 2 - 5 } & Total & 22.278 & 94 & & & \\
\hline
\end{tabular}

It is evident from the table (10) that there is no difference in the level of health locus of control, according to the economic level.

Table 11: The Relationships among Research Variables

\begin{tabular}{|l|l|l|l|l|}
\hline No & Variable X & Variable Y & R & Sig \\
\hline 1 & Nutrition Domain & Health Awareness Level & $.750^{* *} \cdot$ & 0.000 \\
2 & Personal Health Domain & & $.688^{* *} \cdot$ & 0.000 \\
\cline { 4 - 5 } 3 & Sporting Activities Domain & & $.823^{* *} \cdot$ & 0.000 \\
\hline 4 & Body Domain & & $0.891^{* *}$ & 0.000 \\
\hline 5 & Health Locus of Control Level & $.444^{* *} \cdot$ & 0.000 \\
\hline 6 & Nutrition Domain & Health Locus of Control & $.266^{* *} \cdot$ & 0.009 \\
\cline { 4 - 5 } & Level & $.442^{* *} \cdot$ & 0.000 \\
\hline 8 & Personal Health Domain & $.427^{* *} \cdot$ & 0.000 \\
\hline 10 & Body Domain & $.320^{* *} \cdot$ & 0.002 \\
\hline
\end{tabular}

${ }^{* *}$ Correlation is significant at the 0.01 level (2-tailed)

Table (11) shows the relationships between the level of health awareness and the level of health locus of control. Results revealed that there was a direct correlation between the level of health awareness, and the factors of the body $(\mathrm{r}=0.891)$, sporting activities $(\mathrm{r}=0.823)$, nutrition $(\mathrm{r}=$ $0.750)$, and personal health $(\mathrm{r}=0.688)$. In addition, there is a direct correlation between the level of health awareness and the level of health locus of control. Therefore, this result agrees with the study of Khalafy $(\mathrm{r}=2013)$. Moreover, there is a direct correlation between the level of health locus of control with personal health $(r=0.442)$, sporting activities $(r=0.427)$, body $(r=0.320)$, and nutrition $(\mathrm{r}=0.266)$ respectively.

Table 12: T Regression Model between the level of Health Awareness and Research Variables

\begin{tabular}{|c|c|c|c|c|c|c|c|c|c|}
\hline \multicolumn{2}{|l|}{ Variables } & \multirow[t]{2}{*}{$\mathbf{R}$} & \multirow[t]{2}{*}{$\begin{array}{l}\text { Adjusted } \\
\text { R }\end{array}$} & \multirow{2}{*}{$\begin{array}{l}\text { Model } \\
\text { Constant }\end{array}$} & \multicolumn{2}{|c|}{$\begin{array}{l}\text { Unstandardized } \\
\text { coefficients }\end{array}$} & \multirow{2}{*}{$\begin{array}{l}\text { Standardized } \\
\text { coefficients } \\
\text { Beta }\end{array}$} & \multirow[t]{2}{*}{$\mathbf{t}$} & \multirow[t]{2}{*}{ Sig. } \\
\hline $\begin{array}{c}\text { Independent } \\
X\end{array}$ & $\begin{array}{c}\text { Dependent } \\
Y\end{array}$ & & & & Beta & $\begin{array}{l}\text { Std. } \\
\text { error }\end{array}$ & & & \\
\hline \multirow{2}{*}{$\begin{array}{l}\text { Health locus } \\
\text { of control } \\
\text { level }\end{array}$} & \multirow{7}{*}{$\begin{array}{l}\text { Health } \\
\text { awareness }\end{array}$} & & & Constant & 1.955 & 0.384 & \multirow[t]{2}{*}{0.444} & 5.090 & 0.000 \\
\hline & & 0.444 & 0.189 & $\begin{array}{l}\text { Health } \\
\text { locus of } \\
\text { control } \\
\text { level }\end{array}$ & 0.513 & 0.107 & & 4.782 & 0.000 \\
\hline \multirow{2}{*}{$\begin{array}{l}\text { Nutrition } \\
\text { domain }\end{array}$} & & \multirow[t]{2}{*}{$0.750^{*}$} & \multirow[t]{2}{*}{0.558} & Constant & 0.623 & 0.216 & \multirow[b]{2}{*}{0.750} & 6.699 & 0.000 \\
\hline & & & & $\begin{array}{l}\text { Nutrition } \\
\text { domain }\end{array}$ & 1.787 & 0.057 & & 10.949 & 0.000 \\
\hline \multirow{2}{*}{$\begin{array}{l}\text { Personal } \\
\text { health } \\
\text { domain }\end{array}$} & & \multirow[t]{2}{*}{$0.688^{*}$} & \multirow[t]{2}{*}{0.467} & Constant & 1.787 & 0.222 & \multirow[t]{2}{*}{0.688} & 8.064 & 0.000 \\
\hline & & & & $\begin{array}{l}\text { Personal } \\
\text { health } \\
\text { domain }\end{array}$ & 0.497 & 0.054 & & 9.136 & 0.000 \\
\hline $\begin{array}{l}\text { Sporting } \\
\text { activities }\end{array}$ & & $0.823^{*}$ & 0.673 & Constant & 1.269 & 0.183 & 0.823 & 6.944 & 0.000 \\
\hline
\end{tabular}




\begin{tabular}{|c|c|c|c|c|c|c|c|c|c|}
\hline \multicolumn{2}{|l|}{ Variables } & \multirow[t]{2}{*}{$\mathbf{R}$} & \multirow[t]{2}{*}{$\begin{array}{l}\text { Adjusted } \\
\mathbf{R}\end{array}$} & \multirow{2}{*}{$\begin{array}{l}\text { Model } \\
\text { Constant }\end{array}$} & \multicolumn{2}{|c|}{$\begin{array}{l}\text { Unstandardized } \\
\text { coefficients }\end{array}$} & \multirow{2}{*}{$\begin{array}{l}\text { Standardized } \\
\text { coefficients } \\
\text { Beta }\end{array}$} & \multirow[t]{2}{*}{ t } & \multirow[t]{2}{*}{ Sig. } \\
\hline \multirow[t]{2}{*}{$\begin{array}{c}\text { Independent } \\
\text { X } \\
\end{array}$} & $\begin{array}{c}\text { Dependent } \\
Y\end{array}$ & & & & Beta & $\begin{array}{l}\text { Std. } \\
\text { error }\end{array}$ & & & \\
\hline & & & & $\begin{array}{l}\text { Sporting } \\
\text { activities } \\
\text { domain } \\
\end{array}$ & 0.689 & 0.049 & & 13.950 & 0.000 \\
\hline \multirow[t]{2}{*}{ Body domain } & & \multirow[t]{2}{*}{$0.891^{*}$} & \multirow[t]{2}{*}{0.792} & Constant & 1.061 & 0.146 & \multirow[t]{2}{*}{0.891} & 7.289 & 0.000 \\
\hline & & & & $\begin{array}{l}\text { Body } \\
\text { domain }\end{array}$ & 0.712 & 0.038 & & 18.962 & 0.000 \\
\hline
\end{tabular}

Table (12) shows the regression coefficients between the level of health awareness and the study variables. It turns out that there is a significant slope between the level of health awareness (Y) and the level of health locus of control $(\mathrm{X})$ as in the following equation $(\mathrm{Y}=1.955+0.513 \mathrm{X})$. In addition, there is a significant slope between the level of health awareness and the nutrition domain $(\mathrm{Y}=1.447+0.623 \mathrm{X})$, and there is a significant slope between the level of health awareness and the domain of personal health $(\mathrm{Y}=1.787+0.497 \mathrm{X})$. Moreover, there is a slope between the level of health awareness and the domain of sporting activities ( $\mathrm{Y}=1.269+$ $0.689 \mathrm{X})$. There is a slope between the level of health locus of control and the body domain ( $\mathrm{Y}=$ $1.061+0.712 \mathrm{X})$. Finally, this research stated the following hypotheses:

1. There is a significant difference between hospitality students in the level of health awareness, according to the gender $(t=2.132 ; \mathrm{Sig}=0.036)$.

2. There is no a significant difference between hospitality students in the level of health awareness, according to the economic level $(\mathrm{F}=0.708 ; \mathrm{Sig}=0.495)$.

3. There is no a significant difference between hospitality students in the level of health awareness, according to the place of living $(\mathrm{t}=-0.127$; $\mathrm{Sig}=0.900)$.

4. There is a significant difference between hospitality students in the health locus of control level according to gender $(t=2.419 ; \mathrm{Sig}=0.018)$.

5. There is no a significant difference between hospitality students in the health locus of control level according to the economic level $(\mathrm{F}=0.708 ; \mathrm{Sig}=0.495)$.

6. There is no a significant difference between hospitality students in the health locus of control level according to the place of living $(t=1.378 ; \mathrm{Sig}=0.171)$.

7. There is a direct significant correlation between the level of health awareness and the health locus of control level for hospitality students $(\mathrm{R}=0.444$; $\mathrm{Sig}=0.000)$.

\section{Conclusion}

Health is the most important aspect of a person's life. In addition, education is one of the basic social determinants of health and a guarantee of its existence. Thus, the issue of health is an important for educational institutions and students. Whereas poor health leads to decreased educational attainment and educational setbacks at the level of students and educational institutions. Hence, measuring and improving health awareness is one of the basic objectives of education. In this context, several studies have dealt with measuring the level of health awareness among students in various educational institutions in different countries. The level of health awareness in a continuation between high, medium and low. Therefore, the problem of this study was to measure the level of health awareness among first-stage students in the hotel management department at the faculty of tourism and hotels at Minia university in Egypt during the first semester of the academic year 2019/2020.

By analyzing the results of the questionnaire that was distributed to the students, it was found that the level of health awareness and the level of health control among students are high. In 
addition, they differed significantly among students, according to the gender in favor of males. There is a direct correlation between the level of health awareness and the level of health locus of control. Consequently, this calls on educational institutions to promote health awareness among students, especially female students. Tourism and hotels faculties should have an integrated scientific content of the health awareness in the curricula, increasing lectures or research activities in this regard so that students are motivated to follow sound health practices to preserve health and prevent disease. Finally, educational institutions must take into account the level of health locus of control when improving the level of health awareness. Whereas the ability of students to control and perceive healthy behaviors have a clear impact on the level of health awareness.

\section{Recommendations}

The study suggests the following recommendations to the faculties of tourism and hotels:

1. Focusing on curricula that are concerned with improving the level of health awareness and the level of health control to the highest levels among students.

2. Interest in student research in hotel management departments that promote health awareness and the ability to control health among hospitality students.

3. Improving the domains of sporting activities, nutrition, body, and personal health among hospitality students.

4. Gender should be taken into consideration when improving the level of health awareness and the level of health locus of control among the hospitality students.

5. Attention must be paid to the health awareness level when improving the level of health control for hospitality students and vice versa.

6. Hospitality students are advised to avoid believing that things that happen negatively to health happen by chance.

7. Hospitality students are advised to cut down on tea and coffee.

8. Hospitality students need to stay away from fried food and prefer cooked food.

9. Hospitality students are advised to take medical examinations after recovering from injuries.

10. Hospitality students are advised to take care of medical tests before joining sports teams.

11. Hospitality students are advised to no blame themselves for the disease.

\section{Limitations and Future Researches}

This study was applied to first-stag students at the Faculty of Tourism and Hotels, Minia University, and due to the small size of the sample, the results cannot be generalized. Therefore, this research recommends conducting further studies in the faculties of tourism and hotels. In addition, the studies must include all stages and focus on increasing the sample size. Moreover, this study recommends researchers to measure the level of health awareness in light of the demographic variables of students at all levels from the first year to the fourth year.

\section{Reference}

Abdalhaqq, E., Shana'eh, M., Nu'erat, Q., \& Al-Ahmad, S., (2012). The Health Awareness Level for the students of Al-Najah National University \& Jerusalem University. The Journal of AlNajah University for Researches (Humanitarian Sciences), 26 (4), 939-958.

Ahmad, N., (2012). The Effectiveness of Health Education Methods in Instilling \& Disseminating Health Information for Building the Sudanese Health Community of Practice. The National Centre for Researches, The Centre of Documentation \& Information, 17621781.

Al-Ali, S., (2001). The Level of Health Education among the Upper Basic Stage Students in the Public Schools of Jenin. MA Dissertation, Al-Najah National University, Nablus, Jerusalem. 
Almohaithef, M., \& Elsayed, E., (2019). Health education in schools: An analysis of health educator role in public schools of Riyadh, Saudi Arabia. Saudi Journal for Health Sciences, 8 (1), 31-37.

Alonazi, W., Albaiz, A., Albejaidi, F., \& Alenazi, F., (2016), Health Awareness among Female, Undergraduate Medical Students in Saudi Arabia, The Southeast Asian journal of tropical medicine and public health, 47 (1), 121-130.

Al-Sharaa, A., (2019). Health Behaviour and its Relationship with the Physical Fitness Level of the Students of Ajloun College at Balqa Applied University. International Journal of Innovation, Creativity and Change, 8 (4), 177- 198.

Amin, S., Shaheen, H., \& Omran, H., (2016). Smoking among university students in Kafr ElSheikh University. Menoufia Medical Journal, 29 (4), 1092-1099.

Ashraah, M., Mahasneh, A., Al-Sawalmeh, A., \& Abusheikh, A., (2013). Health Awareness among University Students in Jordan. Review of European Studies, 5 (5), 197-204.

Azar, J., Halley, M., Lv, N., Wulfovich, S., Gillespie, K., Liang, L., \& Rosas, G., (2020). Differing views regarding diet and physical activity: adolescents versus parents' perspectives. Int J Environ Res Public Health, 20 (137), 1-10.

Banna, C., Buchthal, V., Delormier, T., Creed-Kanashiro, M., and Penny, E., (2016). Influences on eating: a qualitative study of adolescents in a periurban area in Lima, Peru. BMC Public Health, 15, 16-40.

Bardi, J., (2020). Raising Awareness of Mental Health in Higher Education: Research Activity for Educators. Nurse Educator, 45 (2), 65.

Barile, N., (2020), The Importance of Mental Health Awareness in Schools, https://www.wgu.edu/heyteach/article/importance-mental-health-awarenessschools1810.html, accessed 25/3/2020/

Bossema, J., (2017), Increasing students' safety awareness in a teaching hotel, Research in Hospitality Management, 4 (1-2), 85-90.

Cai, Z., Zhang, Z., Zeng, M., Xian, J., Lei, X., Zhao, Y., (2020). Differences in Lifestyle Behaviors of Students between Inner Urban and Peri-urban High Schools: A Cross-Sectional Study in Chongqing, China. Int J Environ Res Public Health, 17 (7), 2282.

El-Wakeel, L., \& El-Ahmady, S., (2017). The Effects of Nutrition Awareness and Knowledge on Health Habits and Performance Among Pharmacy Students in Egypt. Journal of Community Health, 42 (2), 213-220.

Gelany, S., \& Moussa, O., (2012). Reproductive health awareness among educated young women in Egypt. International Journal of Gynecology and Obstetrics, 120 (1), 23-26.

Heide, I., Wang, J., Droomers, M., Spreeuwenberg, P., Rademakers, J., \& Uiters, E., (2013). The Relationship Between Health, Education, and Health Literacy: Results From the Dutch Adult Literacy and Life Skills Survey. Journal of Health Communication, 18 (1), 172-184.

ICPD (1994), Proposed domains and indicators linked to the definition of RH adopted at the International Conference on Population and Development (ICPD) in 1994, retrieved from http://www.who.int/topics/reproductive_health/en/ access 15/2/2020.

Iqbal, J., Ali, A., \& Ahmad, M. (2020). Comparison of Health Awareness among Public and Private Secondary School Students in District Bahawalpur. Pakistan Social Sciences Review, 4 (2), 638-646.

Kotera, Y., Adhikari, P., and Gordon, W. (2018). Motivation Types and Mental Health of UK Hospitality Workers. International Journal of Mental Health and Addiction, 16 (2), 751-763.

Mahajan, P., \& Sharma, N., (2005). Awareness level of adolescent girls regarding HIV/AIDS: a comparative study of rural and urban areas of Jammu. J Hum Ecol, 17 (4), 313-314. 
Mursi, A., (2005). General Health \& Health Education, Al-Khreiji Dar for publishing \& distribution, Riyadh.

O'liewa, A., (1999). Health in the Sporting Domain, Al-Ma'aref Association, Alexandria, Egypt.

Pinto, A., Pauzé, E., Mutata, R., Gagnon, R., Kent, P., (2020). Food and Beverage Advertising to Children and Adolescents on Television: A Baseline Study. Int J Environ Res Public Health, 17(6), 1999.

Pourhoseinzadeh, M., Gheibizadeh, M., Moradikalboland, M., \& Cheraghian, B., (2017). The Relationship between Health Locus of Control and Health Behaviors in Emergency Medicine Personnel. Int. J. Community Based Nurs Midwifery, 5(4), 397-407,

Refaat, A., (2014). Practice and awareness of health risk behaviour among Egyptian university students. East Mediterr Health J, 10(1-2), 72-81.

Researchomatic, (2012), Health Awareness.

Senthilkumar, R., \& Ulaganathan, G., (2017). Health Information Awareness among the Teaching Professionals of Higher Education: An Analysis. J Adv Res Lib Inform Sci, 4(1\&2), 8-11.

Story, M., Sztainer, N., \& French, S., (2002). Individual and environmental influences on adolescent eating behaviors. J Am Diet Assoc, 102(3), 40-51.

Surveysystem (2020), Sample Size Calculator.

Truman, B., \& Hahn, R. (2015), Education Improves Public Health and Promotes Health Equity, Int J Health Serv., 45(4), 657-678.

UNESCO (2020), Education for health and well-being.

VCU (2015), Why Education Matters to Health: Exploring the Causes.

Verstraeten, R., Royen, K., Ochoa-Avilés, A., Penafiel, D., Holdsworth, M., Donoso, S., Maes, L., \& Kolsteren, P., (2014). A conceptual framework for healthy eating behavior in Ecuadorian adolescents: a qualitative study. PloS One, 9(1), 1-7.

Wallston, A., Wallston, S., \& DeVellis, R., (1978). Development of the Multidimensional Health Locus of Control (MHLC) Scales. Health Educ Monogr, 6(2), 160-170,

Wittayapun, Y., Tanasirirug, V., Butsripoom, B., \& Ekpanyaskul, C., (2010). Factors Affecting Health-promoting Behaviors in Nursing Students of the Faculty of Nursing Srinakharinwirot University. Thailand. J Public Health, 40(2), 15-25.

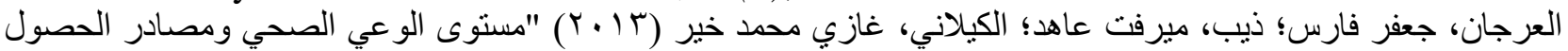

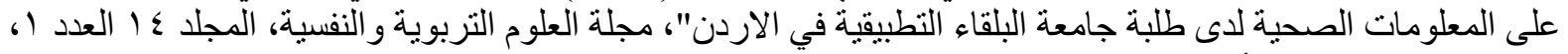

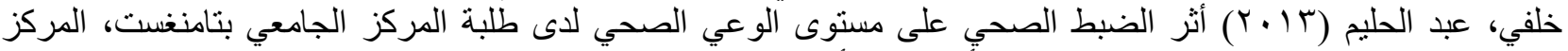

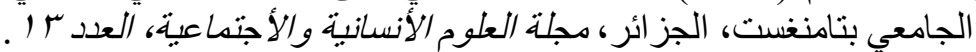

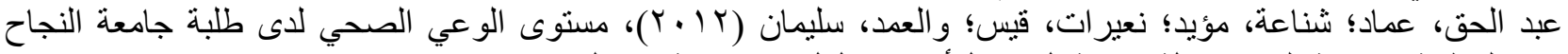

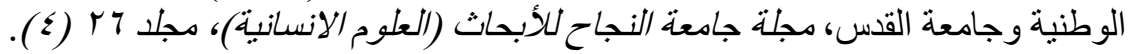

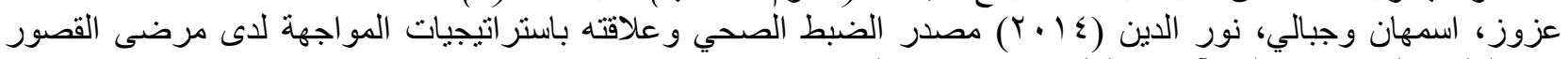

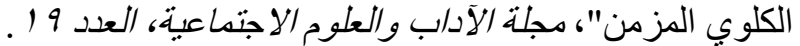

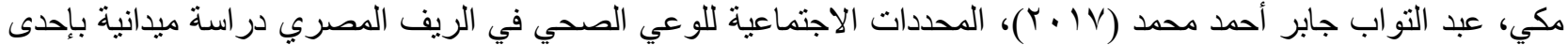

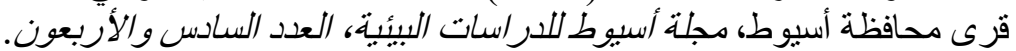

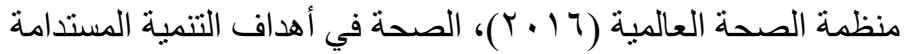

